\title{
CRYBG1 wt Allele
}

National Cancer Institute

\section{Source}

National Cancer Institute. CRYBG1 wt Allele. NCI Thesaurus. Code C54321.

Human CRYBG1 wild-type allele is located in the vicinity of $6 q 21$ and is approximately 211 $\mathrm{kb}$ in length. This allele, which encodes beta/gamma crystallin domain-containing protein 1 , plays a role in melanocyte differentiation and is a candidate tumor suppressor gene. 